\title{
Is it possible to use specific lgE to single latex allergens to discriminate between spina patients with natural rubber latex allergy and sensitization?
}

\author{
Reinhold Cremer ${ }^{1 *}$, Hans-Peter Rihs², Angela Gaspar ${ }^{3}$, Graca Pires ${ }^{3}$, Monika Raulf-Heimsoth ${ }^{2}$ \\ From 54th Annual Meeting of the Society for Research into Hydrocephalus and Spina Bifida \\ Vancouver, Canada. 7-10 July 2010
}

\section{Background}

Eleven characterized allergens of Hevea brasiliensis are available as recombinant proteins for in vitro IgE diagnosis. Hev b 2 and Hev b 13 are only suitable as native proteins. By testing patient sera against this panel of recombinant and native allergens of Hevea brasiliensis individual sensitization profiles and the relevance of single allergens can be assessed.

\section{Materials and methods}

Sera of 30 spina bifida patients with specific IgE to NRL were tested for allergen-specific IgE antibodies (sIgE) to natural rubber latex (NRL) and 13 single Hev b allergens using the ImmunoCAP system. The results of the specific IgE values against single allergens were plotted (frequency of antibodies against the single allergen vs. the percentage of the total latex-specific IgE-response). Minor and major allergens for spina bifida patients sensitized or allergic against NRL could be identified.

\section{Results}

Regarding all 30 spina bifida patients with sIgE Hev b 1, 2, 3, 5, 6.01 and 13 were identified as major Hev b allergens. In the patients without latex-related symptoms Hev b 2 and Hev b 6.01 were found only in small percentages of the latex-specific IgE response and low frequencies (minor allergens) whereas in patients with latex-related symptoms these allergens were found in high concentrations and frequencies. Hev b 5 represents the allergen with the highest percentage of the latex specific IgE response in all groups of patients, Hev b 1 is the allergen with the highest frequency of sensitization (about $80 \%$ ) in all groups.

\section{Conclusions}

Latex extracts for skin prick testing or in vitro allergosorbents should contain the major allergens $\mathrm{Hev}$ b 1,2 , 3, 5, 6.01 and 13. In spina bifida patients Hev b 6.01 and Hev b 2 could be useful to distinguish sensitized from allergic patients.

\section{Acknowledgements}

This article has been published as part of BMC Bioinformatics Volume 11 Supplement 12, 2010: Proceedings of the 11th Annual Bioinformatics Open Source Conference (BOSC) 2010. The full contents of the supplement are available online at http://www.biomedcentral.com/1471-2105/11?issue=S12.

\section{Author details}

${ }^{1}$ Children's Hospital, Clinics of the City of Cologne, Amsterdamer Str. 59, 50735 Cologne, Germany. ${ }^{2}$ Institute of Prevention and Occupational Medicine of the German Social Accident Insurance, Ruhr-University Bochum, Germany. ${ }^{3}$ Immunoallergy Department, Dona Estefania Hospital, Lisbon,

Portugal.

Published: 15 December 2010

doi:10.1186/1743-8454-7-S1-S17

Cite this article as: Cremer et al.: Is it possible to use specific IgE to single latex allergens to discriminate between spina patients with natural rubber latex allergy and sensitization? Cerebrospinal Fluid Research 2010 7(Suppl 1):S17.

\footnotetext{
* Correspondence: CremerR@kliniken-koeln.de

'Children's Hospital, Clinics of the City of Cologne, Amsterdamer Str. 59,

50735 Cologne, Germany

Full list of author information is available at the end of the article
}

(c) 2010 Cremer et al; licensee BioMed Central Ltd. This is an open access article distributed under the terms of the Creative Commons 